\title{
EFFICACY OF RICE BRAN FERMENTATION IN COSMETICS AND SKIN CARE PRODUCTS
}

\author{
EFICÁCIA DA FERMENTAÇÃO DE FARELO DE ARROZ EM COSMÉTICOS E \\ PRODUTOS PARA CUIDADOS COM A PELE
}

\author{
CHEN L. H ${ }^{1}$; CHEN I. $C^{1}$.; CHEN P. $\mathbf{Y}^{1}$.; HUANG P. H ${ }^{1} *$ \\ 1. Depart. of Cosmetic Applications and Management, College of Cardinal Tien Junior College of Healthcare and Management. No. \\ 112, Minzu Road, Sindian District. New Taipei City 23143, Taiwan, (ROC).*pshuang@cten.edu.tw
}

\begin{abstract}
This study aims to develop rice bran-based skin care products with moisturizing, whitening and anti-wrinkle effects similar to Pitera (a natural by-product of sake lees fermentation) but without alcohol irritation for sensitive skin. To achieve this objective, bran from organic indica rice was fermented by lactic acid bacteria in a safe and pollution-free environment. In terms of anti-oxidation, the DPPH · free radical scavenging ability of $100.0 \mathrm{mg} / \mathrm{mL} \mathrm{bran}$ fermentation solution was $71.4 \%$ of that of vitamin $\mathrm{C}$ of the same concentration; and its $\mathrm{Fe}^{2+}$ chelating ability was $79.0 \%$ of that of EDTA of the same concentration. Moreover, the superoxide anion scavenging ability of $10.0 \mathrm{mg} / \mathrm{mL} \mathrm{bran}$ fermentation solution was equivalent to $42.9 \%$ of that of BHT of similar concentration. With respect to inhibition of melanin synthesis, the bran fermentation solution's ability to inhibit the synthesis of dopachrome, the intermediate of melanin, was positively correlated to its concentration, i.e., the higher the concentration of the bran fermentation solution was, the better the inhibition ability was. The $\mathrm{IC}_{50}$ of bran fermentation solution was $9.23 \mathrm{mg} / \mathrm{mL}$ while, for comparison, that of arbutin was $0.52 \mathrm{mg} / \mathrm{mL}$. Furthermore, according to the cell survival assay, no obvious cytotoxic effect was found with the increase of the concentration of the bran fermentation solution. As for whitening evaluation, the whitening improvement rate was $9.29 \%$ in $20 \%$ dilution, $5.36 \%$ in $15 \%$ dilution, $3.69 \%$ in $10 \%$ dilution, $2.43 \%$ in $5 \%$ dilution, $0.35 \%$ in $1 \%$ dilution in a 30 -day test. In the moisturizing evaluation, the moisturizing improvement rate was $44.31 \%$ in $20 \%$ dilution, $20.48 \%$ in $15 \%$ dilution, $7.68 \%$ in $10 \%$ dilution, $6.02 \%$ in $5 \%$ dilution and $2.02 \%$ in $1 \%$ dilution. Based on the experimental results, the alcohol-free rice bran fermentation solution not only did not cause irritation but also had antiaging, melanin synthesis inhibition, whitening and moisturizing effects. Therefore, it is advisable to add rice bran fermentation solution to cleaning mousse, shower gel, serum and essence to turn bran from compost of agricultural waste (cradle to grave) into a natural raw material (cradle to cradle) of the cosmetic industry, creating new value of rice bran.
\end{abstract}

KEYWORDS: Rice Bran. Lactic acid bacteria. Alcohol-free fermentation. Anti-oxidation. Anti-aging. Whitening. Cosmetics.

\section{INTRODUCTION}

Rice bran is the waste in the rice polishing process, which turns brown rice to polished white rice. It mainly consists of yellowish outer layers of pericarp, seed-coat and part of germ. According to literature (FU, 2001; TSAI, 2014; HE, 2014; KAYAHARA et al., 2000; VILLAREAL et al., 1991), the calorie of brown rice and white rice is similar. However, at least $50 \%$ of nutrients, including fat, fiber, ash, calcium, phosphorus, iron, vitamins $\mathrm{A}$, vitamins B1, B2, B6, vitamin E, amino acids and nicotinic acid are lost from the polishing process. The rice bran contains the lost nutrients that can effectively prevent dry skin, delay skin aging and avoid pigment deposition. It is wasteful to discard the valuable rice bran as waste or compost.
Based on literature (YANG, 2011; CHANG, 2014; PENG, 2007; CHEN, 2014; WU, 2007; LIU, 2012; TU, 2010; CHAO et al., 2006) and users' experience of lees-based beauty products on the market (SHEN, 1990; CHANG et.al., 2012; HUANG, 1991; CHANG, 1998), we used rice bran from organic rice as the experimental material and applied yeast fermentation technique to produce alcohol-free rice bran fermentation solution, which is different from the white rice-based and yeastfermented lees. We evaluated the whitening, moisturizing, anti-oxidation, melanin synthesis inhibition, and mutation effects of the rice bran fermentation solution before developing cleansing and skin care products, such as shower gel, cleansing mousse and essence as the overture of the rice bran legend (Figure 1). 


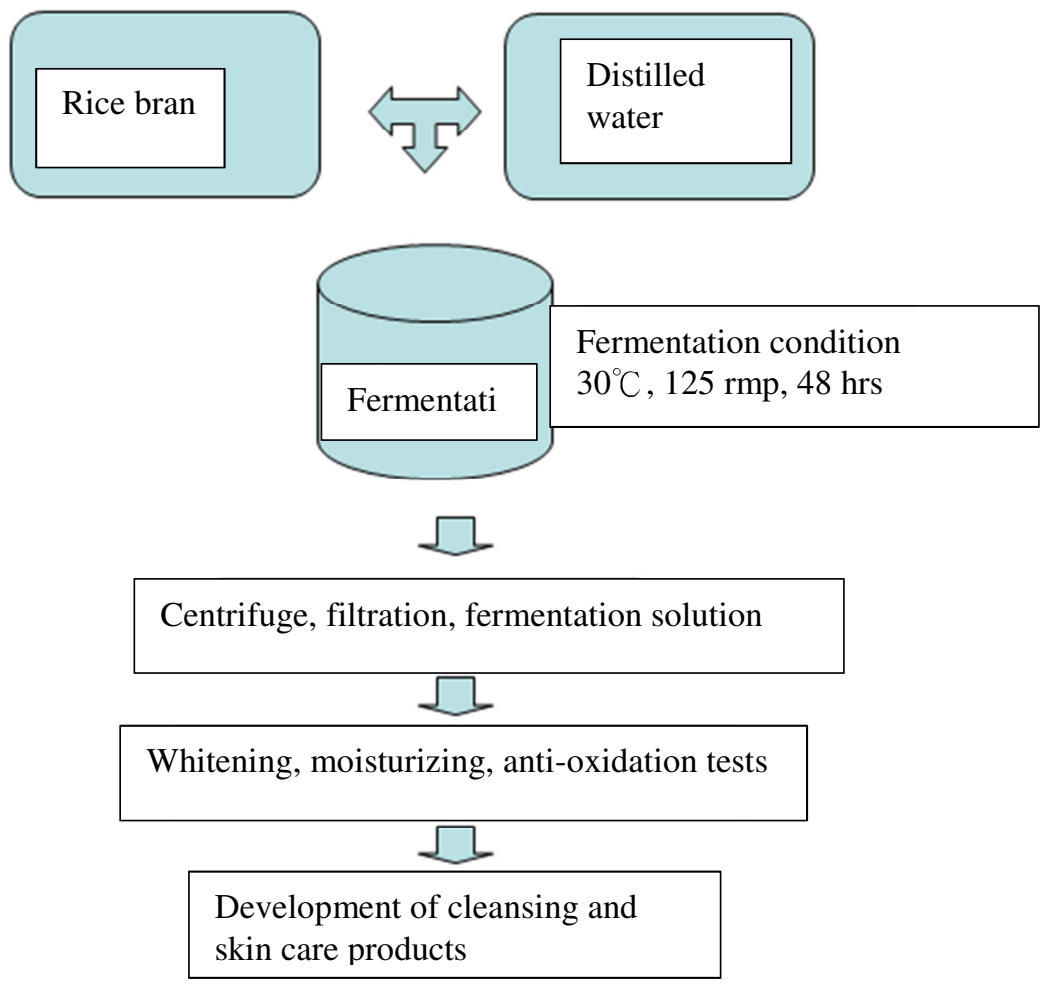

Figure 1. Development of cleansing and skin care products from rice bran fermentation

\section{MATERIAL AND METHODS}

\section{Preparation of rice bran fermentation solution}

First, $0.2 \mathrm{~g}$ lactic acid bacteria were added to $10 \mathrm{~mL}$ of fermentation solution (formula as Table 1) for 24-hour culture. Then, $3 \mathrm{~mL}$ culture medium was added to the fermentation solution of Table 1 to make 1 liter solution for 48-hour fermentation at $30^{\circ} \mathrm{C}$ and $125 \mathrm{rpm}$. (The rice bran fermentation solution must be sterilized by an autoclave and then cooled down to room temperature before inoculation.).

Table 1. Bran fermentation formula

\begin{tabular}{ll}
\hline Approximate & Per Liter \\
\hline Rice Bran & $50.0 \mathrm{~g}$ \\
Proteose Peptone No.3 & $10.0 \mathrm{~g}$ \\
Yeast Extract & $5.0 \mathrm{~g}$ \\
Dextrose & $20.0 \mathrm{~g}$ \\
Polysorbate 80 & $1.0 \mathrm{~g}$ \\
Ammonium Citrate & $2.0 \mathrm{~g}$ \\
Sodium Acetate & $5.0 \mathrm{~g}$ \\
Magnesium Sulfate & $0.1 \mathrm{~g}$ \\
Dipotassium Phosphate & $2.0 \mathrm{~g}$ \\
\hline
\end{tabular}

\section{DPPH • free radical scavenging ability}

The method was performed as described by Yamaguchi et al. (1998). A mixture of $100 \mu \mathrm{L}$ rice bran fermentation solution, $400 \mu \mathrm{L}$ of $100 \mathrm{mM}$ Tris$\mathrm{HCl}$ buffer $(\mathrm{pH}=7.4)$ and $500 \mu \mathrm{L}$ of $250 \mu \mathrm{M} \mathrm{DPPH}$ - free radical ethanol solution was well mixed in a microcentrifuge tube before the tube was placed in a $25^{\circ} \mathrm{C}$ thermostatic reactor for 20 minutes followed by $\mathrm{OD}_{517}$ measurement of the solution by a UV- Vis spectrophotometer. This test was repeated for three times. The DPPH - free radical scavenging rate is calculated as follows:

DPPH - free radical scavenging rate $(\%)=[1-$

$\left(\mathrm{OD}_{517}\right.$ of sample/OD $\mathrm{OD}_{517}$ of blank solution] $\times 100 \%$

\section{$\mathrm{Fe}^{2+}$ chelating ability}

The method was performed as described by Dinis et al. (1994). First, $0.1 \mathrm{~mL}$ rice bran 
fermentation solution, $3.7 \mathrm{~mL}$ of $95 \%$ ethanol and $0.1 \mathrm{~mL}$ of $2 \mathrm{mM} \mathrm{FeCl}{ }_{2} \cdot 4 \mathrm{H}_{2} \mathrm{O}$ solution were added to a sample bottle and was left for 30 seconds at room temperature. Next, $0.2 \mathrm{~mL}$ of $5 \mathrm{mM}$ ferrozine solution was added to the sample bottle and was left for reaction for 10 minutes at room temperature. $\mathrm{OD}_{562}$ of the sample was measured by the UV- Vis spectrophotometer. This test was repeated for three times. The $\mathrm{Fe}^{2+}$ chelating ability is calculated as follows:

The $\mathrm{Fe}^{2+}$ chelating ability $(\%)=\left[1-\left(\mathrm{OD}_{562}\right.\right.$ of sample/ $\mathrm{OD}_{562}$ of blank solution] $\times 100 \%$

\section{Superoxide anions scavenging ability $\left(\mathrm{O}_{2}\right)$}

The method was performed as described by Fried et al. (1996). First, $0.25 \mathrm{~mL}$ rice bran fermentation solution and $1 \mathrm{~mL}$ mixture solution (pH 7.4, $0.1 \mathrm{M}$ phosphate buffer added with $100 \mu \mathrm{l}$ of $10 \mu \mathrm{M}$ PMS, $50 \mu \mathrm{l}$ of $78 \mu \mathrm{M}$ NADH and $100 \mu$ of $50 \mu \mathrm{M}$ NBT to $1 \mathrm{~mL}$ ) were added to a sample bottle, and then the sample bottle was placed in $25^{\circ} \mathrm{C}$ thermostatic water bath for 10 minutes. Then, 0.25 $\mathrm{mL}$ of 1.2 units $/ \mathrm{mL}$ xanthine oxidase was added to the bottle, and the solution was left for reaction for two minutes in the $25^{\circ} \mathrm{C}$ thermostatic water bath. $\mathrm{OD}_{532}$ of the sample was measured by the UV- Vis spectrophotometer. Next, xanthine oxidase was replaced with $0.1 \mathrm{M}$ Tris- $\mathrm{HCl}$ buffer $(\mathrm{pH}=7.4)$, and the absorbance of the sample at $532 \mathrm{~nm}$ measured was $\mathrm{A}_{1}$.

Next, sample was replaced by DMSO, and the absorbance of the sample at $532 \mathrm{~nm}$ measured was $\mathrm{A}_{\mathrm{b}}$. Finally, the sample and xanthine oxidase were replaced by DMSO and phosphate buffer solution, respectively, and the absorbance of the sample at $532 \mathrm{~nm}$ measured was $A_{b}$. This test was repeated for three times. The $\mathrm{O}_{2}{ }^{-}$scavenging rate is calculated as follows:

$$
\mathrm{O}_{2} \text { - scavenging rate }=\left[\left(\mathrm{A}_{\mathrm{b}}-\mathrm{A}_{0}\right)-\left(\mathrm{A}_{\mathrm{t}}-\mathrm{A}_{1}\right) /\left(\mathrm{A}_{\mathrm{b}}-\right.\right.
$$

$$
\left.\left.\mathrm{A}_{0}\right)\right] \times 100 \%
$$

\section{Melanin synthesis inhibition ability}

The method was performed as described by Lee et al. (1997). A mixture of $1 \mathrm{~mL}$ rice bran fermentation solution, $0.9 \mathrm{~mL}$ of phosphate buffer solution $(\mathrm{pH}=6.8)$ and $1 \mathrm{~mL}$ of $0.03 \%$ tyrosine aqueous solution was well mixed in a sample bottle, and then the bottle was placed in $37^{\circ} \mathrm{C}$ thermostatic water bath for 10 minutes. Next, $0.1 \mathrm{~mL}$ of 350 units $/ \mathrm{mL}$ tyrosinase was added to the solution, and the well-mixed solution was reacted in the thermostatic water bath for 25 minutes. The absorbance of the solution at $475 \mathrm{~nm}$ measured by the UV-Vis spectrophotometer was $A_{t}$. Then, the tyrosinase was replaced by phosphate buffer solution, and the absorbance of the solution at 475 $\mathrm{nm}$ measured was $\mathrm{A}_{1}$. Next, the rice bran fermentation solution was replaced by deionized water, and the absorbance of the solution at $475 \mathrm{~nm}$ measured was $A_{b}$. Finally, the rice bran fermentation solution and tyrosinase were replaced by distilled water and phosphate buffer solution, respectively, and the absorbance of the solution at $475 \mathrm{~nm}$ measured was $A_{0}$. This test was repeated for three times. The $\mathrm{O}_{2}$ removal rate is calculated as follows: Dopachrome inhibition rate $(\%)=\left[\left(\mathrm{A}_{\mathrm{b}}-\mathrm{A}_{0}\right)-\left(\mathrm{A}_{\mathrm{t}}\right.\right.$

$$
\left.\left.-\mathrm{A}_{1}\right) /\left(\mathrm{A}_{\mathrm{b}}-\mathrm{A}_{0}\right)\right] \times 100 \%
$$

$\mathrm{IC}_{50}(50 \%$ inhibition concentration) is the concentration of rice bran fermentation solution that inhibits $50 \%$ of dopachrome synthesis, and was obtained by a linear regression curved constructed based on the dopachrome inhibition rate under different concentration of the rice bran fermentation solution.

\section{Cell survival assay}

The method was performed as described by Kazuho Abe et al. (1999). Cell survival assay is usually performed using 3-(4,5-dimethylthiazol-2yl)-2,5-diphenyl- tetrazolium bromide (MTT). Therefore, this assay is called MTT test or Tetrazolium assay. MTT is a yellow water-soluble substance, which can be metabolized by dehydrogenase in mitochondria in cells. The activity of dehydrogenase is positively correlated with cellular respiration. Thus, the cell activity can be measured following this principle.

When the tetrazolium ring of MTT is cut off by dehydrogenase, the MTT is reduced to purple crystal formazan (3-[4,5-dimethylthiazol-2-yl]-2,5diphenyl-formazan), accumulating in the cells. Formazan is soluble in DMSO and its concentration can be measured by a spectrophotometer at $570 \mathrm{~nm}$. The higher the cell survival rate is or the more the cell number is, the more accumulated purple crystal is.

Therefore, MTT test is often used to assess the cell survival rate. Five milligrams of 3-(4,5dimethylthiazol-2-yl)-2,5-diph-enyl-tetrazolium bromide (MTT) was dissolved in $1 \mathrm{~mL}$ sterile PBS and filtered by a $0.45 \mu \mathrm{m}$ membrane before it was stored at $4^{\circ} \mathrm{C}$. Mouse fibroblast 3T3 cells were cultured in a 96-well plate $(1 \times 105$ cells/ 0.1 $\mathrm{mL} /$ well). After 24 hours, the old culture medium was aspirated and culture media of different concentration were added to the plate. After 24 hours of incubation, the old culture media were aspirated. The cells were rinsed with PBS twice and $100 \mu \mathrm{L}$ MTT $(0.5 \mathrm{mg} / \mathrm{mL})$ was added to the cells. 
Then, the cells were incubated in a $37^{\circ} \mathrm{C}$ incubator with $5 \% \mathrm{CO}_{2}$ for one hour. Finally, the old culture medium was aspirated before $100 \mu \mathrm{L}$ DMSO was added to the culture, and then the culture left for 10 minutes. The absorbance of the culture was measured by a spectrophotometer at $570 \mathrm{~nm}$.

Cell proliferation $(\%)=($ O.D sample/O.D control $) \times$ $100 \%$

\section{Whitening and moisturizing assay}

(1) Instrument name: three-in-one skin analyzer (SSC3);

(2) Brand: Courage-Khazaka Electronic Gmbh (CK), Germany

(3) Test methods

1. The protocol number of the Human Research Ethics Committee for this research: 201705ES002

2. Sampling: $2 \mathrm{~mL}$ of $20 \%, 15 \%, 10 \%, 5 \%$, $1 \%$ rice bran fermentation solution each.
3. Test spots: forehead and cheek.

4. Test age/skin: 18 to 20 years old females.

5. Test environment: thermostatic indoor temperature at $22^{\circ} \mathrm{C}$.

6. Test area: the test areas were divided into experimental area and control area. Right site was experimental area (for cleansing mousse with rice bran fermentation solution), and the left side was control area (for cleansing mousse without rice bran fermentation solution).

7. Application time: the whole face was cleaned with clean water. After 30 minutes, the first test was conduction. Cleansing mousses without and with rice bran fermentation solution were applied to the left side and right side of the face, respectively, and rinsed off with water. The second test was conducted after another 30 minutes.

Figure 2. Three-in-one skin analyzer

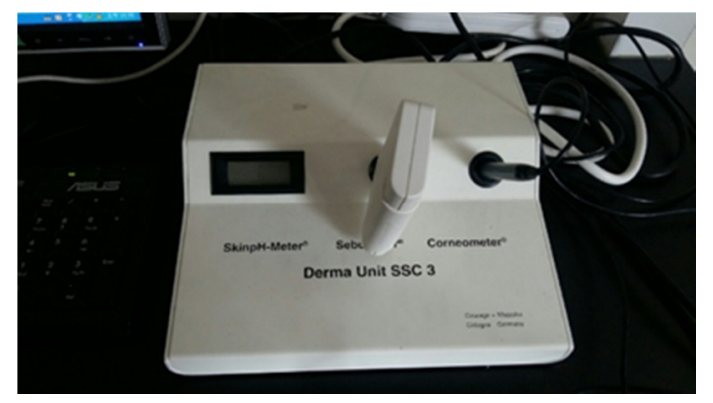

\section{RESULTS AND DISCUSSION}

Anti-oxidation ability of rice bran fermentation solution

\section{DPPH $\cdot$ free radical scavenging ability}

DPPH $\cdot$ free radicals are stable free radicals containing odd number of electrons. When they are combined with other free radicals or reduced by antioxidants, DPPH $\cdot$ free radicals are scavenged $(\mathrm{DPPH} \cdot+\mathrm{AH} \rightarrow \mathrm{DPPH}-\mathrm{H}+\mathrm{A} \cdot)$, and the color is turned from purple to light yellow, which in turn reduces the absorbance.

The lower the absorbance is, the stronger the sample's DPPH - scavenging ability is and the stronger the anti-oxidation ability is. DPPH ethanol solution has very strong absorbance at 517 $\mathrm{nm}$ visible light.

Figure 3 shows the DPPH $\cdot$ scavenging ability of rice bran fermentation solution on DPPH - free radicals. The DPPH - free radical scavenging ability of rice bran fermentation solution increases with the increase of the concentration of rice bran fermentation solution. The DPPH - free radical scavenging ability of $10.0 \mathrm{mg} / \mathrm{mL}$ rice bran fermentation solution was $23.9 \%$, and that of 50.0 $\mathrm{mg} / \mathrm{mL}$ and $100.0 \mathrm{mg} / \mathrm{mL}$ rice bran fermentation solution was $37.4 \%$ and $64.6 \%$, respectively. 


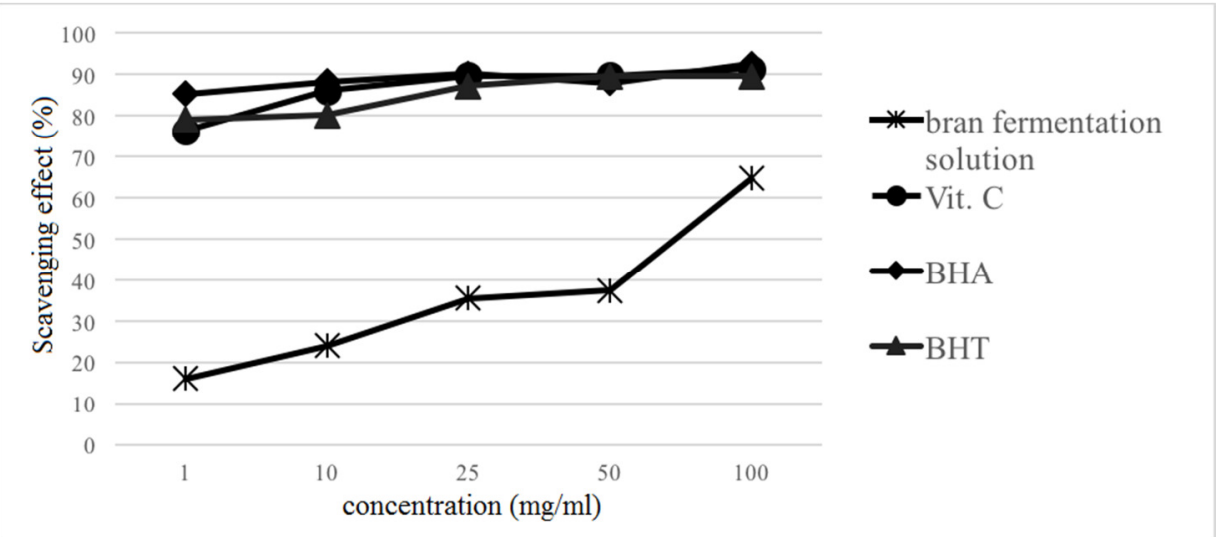

Figure 3. The free radical scavenging ability of rice bran fermentation solution

\section{$\mathrm{Fe}^{2+}$ chelating ability}

In addition to the formation of hydroxyl radicals $(\cdot \mathrm{OH})$ by Fenton reaction, the ferrous ions $\left(\mathrm{Fe}^{2+}\right)$ in the body also reacts with lipid peroxides $(\mathrm{LOOH})$, resulting in oxidative lipid free radicals $\left(\mathrm{LO}^{*}\right)$. Therefore, substrates with iron chelating ability can also act as antioxidant synergists. Therefore, if the rice bran fermentation solution has iron chelating activity, it can act as an antioxidant.

$\mathrm{Fe}^{2+}$ can form a complex with ferrozine. The maximum absorbance of such complex is at $562 \mathrm{~nm}$. The lower the absorbance is, the stronger the sample's $\mathrm{Fe}^{2+}$ chelating ability is. Figure 4 shows the rice bran fermentation solution's chelating ability against $\mathrm{Fe}^{2+}$. Such ability increases with the increase of the concentration of the rice bran fermentation solution. When the concentration of the rice bran fermentation solution was 100.0 $\mathrm{mg} / \mathrm{mL}$, the $\mathrm{Fe}^{2+}$ chelating ability was equivalent to $79.0 \%$ of that of EDTA. However, further studies are required to identify which component in the rice bran fermentation solution is related to $\mathrm{Fe}^{2+}$ chelating, like the chromatography.

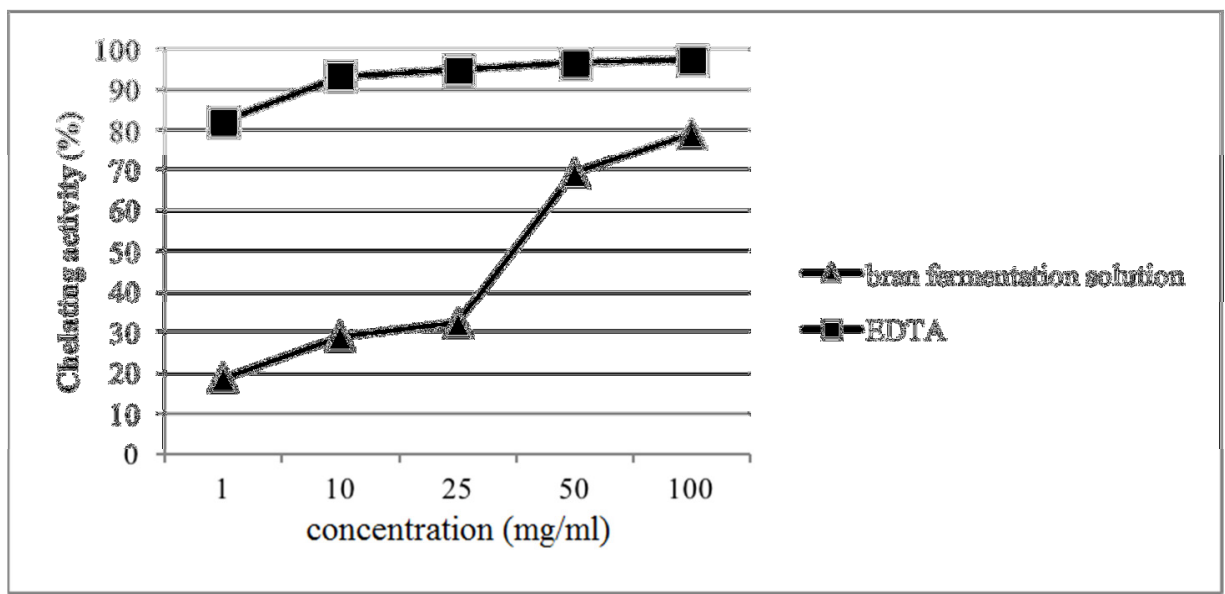

Figure 4. $\mathrm{Fe}^{2+}$ chelating ability of rice bran fermentation solution

\section{Superoxide anion scavenging ability}

In the process of in vivo metabolism, an oxygen molecule forms a superoxide anion with an electron through reduction reaction. The electron transfer chain reaction taking place on the inner mitochondrial membrane in the cytoplasm also results in superoxide anion formation. These processes give rise to $\mathrm{O}_{2}$ free radicals, which cause damage to human cells.

Therefore, $\mathrm{O}_{2}$ - scavenging substrates can act as antioxidants to reduce oxidative damage. The oxidation of xanthine by xanthine oxidase generates
$\mathrm{O}_{2}$, which reduces nitroblue tetrazolium in the reaction reagent to formazan. The maximum absorbance of formazan is at $532 \mathrm{~nm}$. The lower the $\mathrm{OD}_{532}$ is, the better the sample's scavenging ability is. Figure 5 shows the $\mathrm{O}_{2}$ scavenging ability of rice bran fermentation solution, which increases with the increase of the concentration of rice bran fermentation solution. When the concentration of rice bran fermentation solution was $10.0 \mathrm{mg} / \mathrm{mL}$, the $\mathrm{O}_{2}$ - scavenging ability of rice bran fermentation solution was equivalent to $42.9 \%$ of that of BHT of the same concentration. 


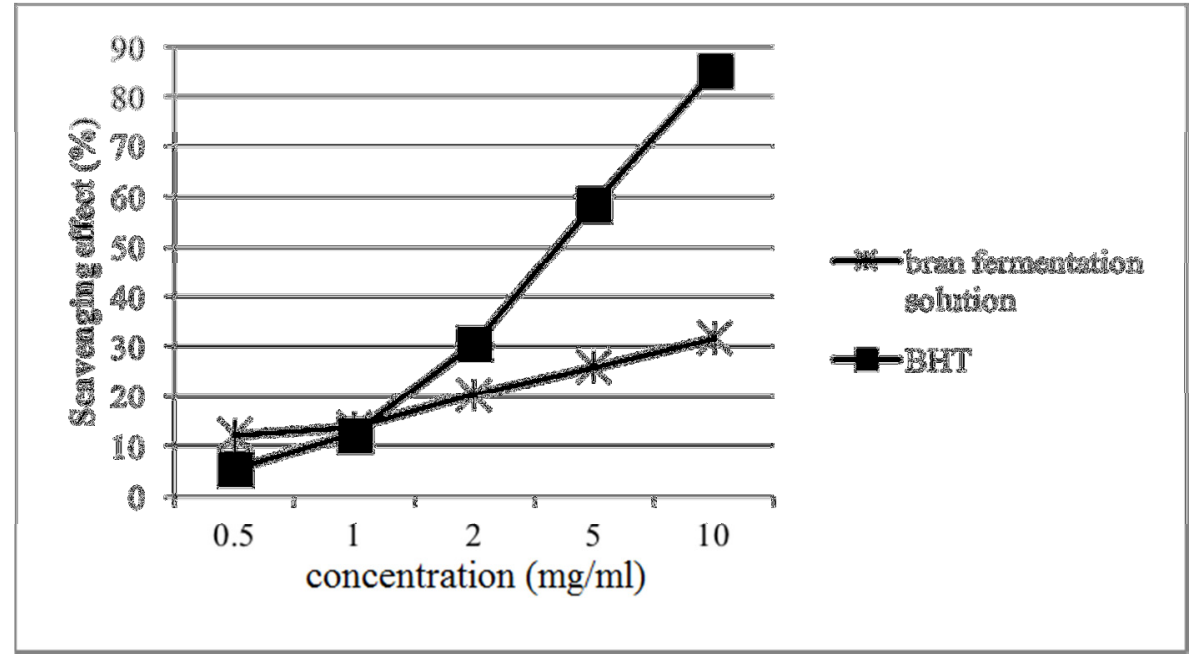

Figure 5. $\mathrm{O}_{2}$ scavenging ability of rice bran fermentation solution

\section{The ability of rice bran fermentation solution to inhibit melanin synthesis}

In the process of melanin synthesis, tyrosine is turned into dopaquinone through the catalysis of tyrosinase. Dopaquinone then forms melanin through a series of reactions. Dopachrome is a more stable intermediate in the process of melanin synthesis, and its maximum absorbance is at 475 $\mathrm{nm}$. The lower the $\mathrm{OD}_{475}$ is, the better the sample's ability to inhibit melanin synthesis.

Figure 6 shows the ability of rice bran fermentation solution to inhibit melanin synthesis. Such ability increased with the increase of the concentration of rice bran fermentation solution, indicating a positive correlation. The $\mathrm{IC}_{50}$ of the rice bran fermentation solution was $9.23 \mathrm{mg} / \mathrm{mL}\left(\mathrm{IC}_{50}\right.$ of Arbutin was $0.52 \mathrm{mg} / \mathrm{mL}$ ).

$\mathrm{Cu}^{2+}$ is a cofactor of tyrosinase, which catalyzes the oxidation reaction of melanin synthesis. If the sample has metal ion chelating ability, it can inhibit melanin synthesis. Based on the results in the anti-oxidation test, the rice bran fermentation solution was able to chelate metal irons. Therefore, it was inferred that the ability of rice bran fermentation solution to inhibit dopachrome synthesis is related to its $\mathrm{Cu}^{2+}$ chelating ability.

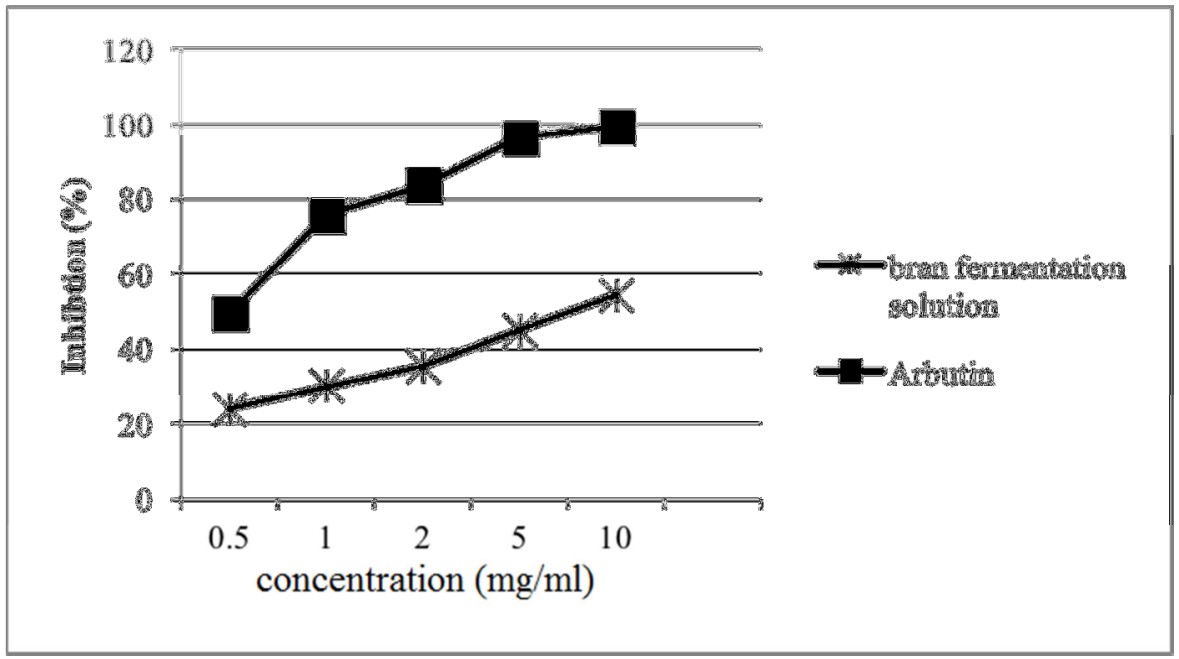

Figure 6. The ability of rice bran fermentation solution to inhibit melanin synthesis

\section{Cell survival assay of rice bran fermentation solution}

MTT is a yellow water-soluble substrate, which can be reduced to blue-violet crystals by dehydrogenase in mitochondria during cellular respiration. The blue-violet crystals accumulated in the cells can be dissolved by DMSO and its absorbance can be measured at $540 \mathrm{~nm}$. The higher the cell survival rate is, the more the blue-violet crystals are produced and the higher the $\mathrm{OD}_{540}$ value is. 
In this study, the rice bran fermentation solution is tested with the cell survival assay. The objective was to observe whether the rice bran fermentation solution is toxic to the cells. Figure 7 is the survival rate of $3 \mathrm{~T} 3$ cells in the rice bran fermentation solution of different concentration. The results indicated that there was no obvious cytotoxic effect on the cells as the concentration of the rice bran fermentation solution was increased.

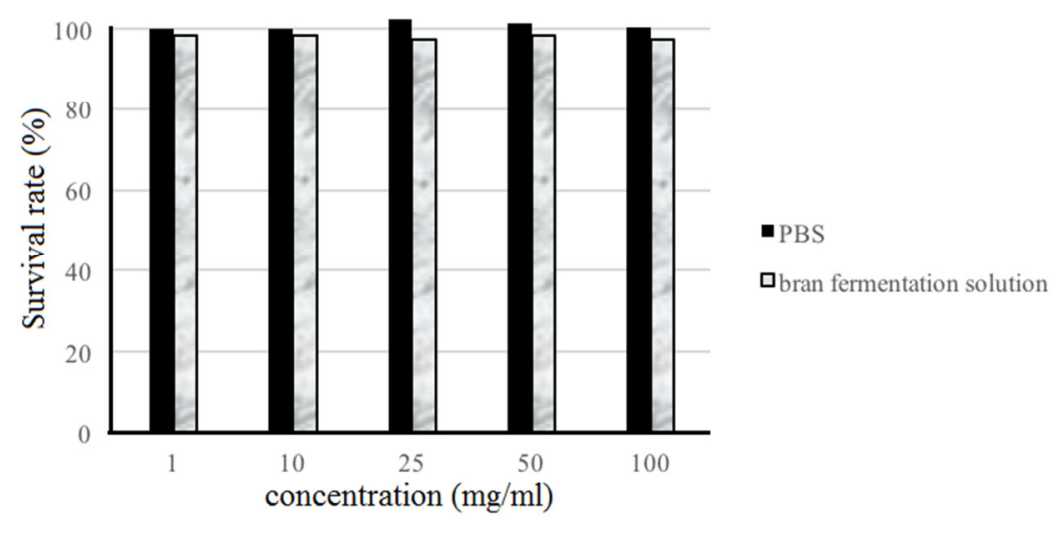

Figure 7. Cytotoxicity of the rice bran fermentation solution

Assessment of moisturizing effect of rice bran fermentation solution

The rice bran fermentation solution was diluted with distilled water, and then filtered and centrifuged. A series of $20 \%, 15 \%, 10 \%, 5 \%$ and $1 \%$ dilution were applied to 20 subjects for the assessment of the moisturizing effect of the rice bran fermentation solution. The average values of the 20 subjects are summarized in Table 2 and Figure 8 , and the moisturizing improvement rate is illustrated in Table 3 and Figure 9.

Table 2. Moisturizing data of experimental group and control group of the rice bran fermentation solution (average values of 20 subjects)

\begin{tabular}{ccccccccccc}
\hline \multirow{2}{*}{$\begin{array}{c}\text { Concentration of } \\
\text { rice bran solution }\end{array}$} & \multicolumn{2}{c}{ Day 1 } & \multicolumn{2}{c}{ Day 8 } & \multicolumn{2}{c}{ Day 15 } & \multicolumn{2}{c}{ Day 23 } & \multicolumn{2}{c}{ Day 30 } \\
\cline { 2 - 10 } & Control & Experimental & Control & Experimental & Control & Experimental & Control & Experimental & Control & Experimental \\
\hline $20 \%$ & 68.6 & 67.3 & 70.3 & 69.5 & 63.5 & 74.8 & 59.0 & 81.6 & 58.0 & 83.7 \\
$15 \%$ & 54.2 & 58.7 & 51.1 & 61.4 & 62.4 & 62.3 & 58.4 & 63.9 & 57.6 & 69.4 \\
$10 \%$ & 57.7 & 59.3 & 57.2 & 61.7 & 55.2 & 61.9 & 58.4 & 62.8 & 58.6 & 63.1 \\
$5 \%$ & 53.5 & 56.4 & 58.8 & 58.3 & 53.5 & 58.7 & 55.2 & 58.7 & 58.1 & 61.6 \\
$1 \%$ & 55.6 & 56.5 & 57.4 & 58.8 & 57.8 & 58.9 & 59.8 & 60.1 & 59.5 & 60.7 \\
\hline
\end{tabular}

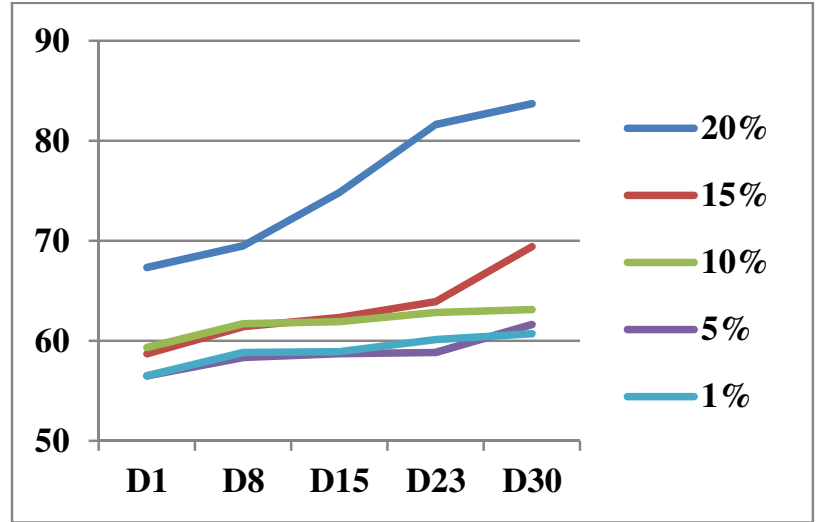

Figure 8. Moisturizing effect of rice bran fermentation solution.

Moisturizing improvement rate $=\frac{\text { experimental group (day 28) }- \text { control group (day 28) }}{\text { control group }(\text { day } 28)} \times 100 \%$ 
Table 3. Moisturizing improvement rate of rice bran fermentation solution after 30 days

\begin{tabular}{llllll}
\hline Variable & \multicolumn{5}{c}{ Value } \\
\hline $\begin{array}{l}\text { Diluted solution } \\
\begin{array}{l}\text { Moisturizing } \\
\text { improvement rate }\end{array}\end{array}$ & $20 \%$ & $15 \%$ & $10 \%$ & $5 \%$ & $1 \%$ \\
\hline
\end{tabular}

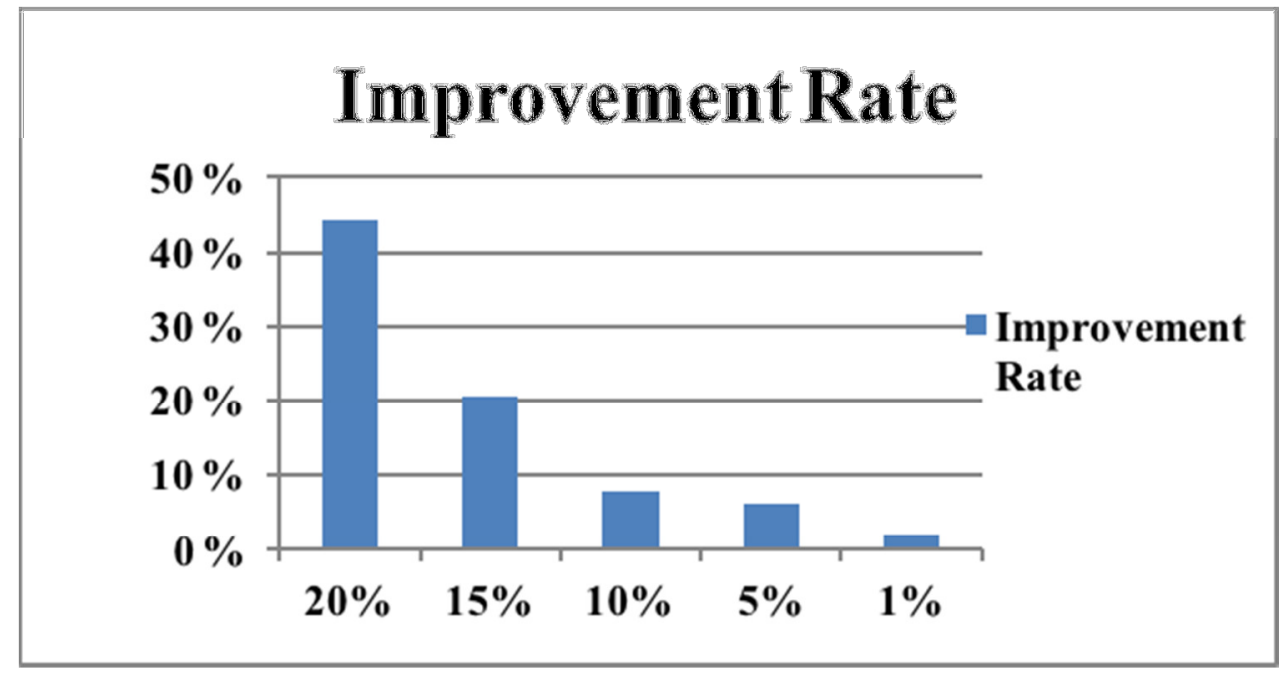

Figure 9. Moisturizing improvement rate of rice bran fermentation solution after 30 days

After 30 days of test on 20 females aged 18 to 20 , the results showed that the higher the concentration of the diluted rice bran fermentation solution is, the better the moisturizing effect is. Based on the experimental data, the $20 \%$ rice bran fermentation solution had the best moisturizing effect.

7. Whitening assessment of rice brand fermentation solution
The rice bran fermentation solution was diluted with distilled water, and then filtered and centrifuged. A series of $20 \%, 15 \%, 10 \%, 5 \%$ and $1 \%$ dilution were applied to 20 subjects for the assessment of the whitening effect of the rice bran fermentation solution. The average values of the 20 subjects are summarized in Table 4 and Figure 10, and the moisturizing improvement rate is illustrated in Table 5 and Figure 11.

Table 4. Whitening data of experimental group and control group of the rice bran fermentation solution (average values of 20 subjects)

\begin{tabular}{|c|c|c|c|c|c|c|c|c|c|c|}
\hline \multirow{2}{*}{$\begin{array}{l}\text { Concentration } \\
\text { of rice bran } \\
\text { solution }\end{array}$} & \multicolumn{2}{|c|}{ Day 1} & \multicolumn{2}{|r|}{ Day 8} & \multicolumn{2}{|c|}{ Day 15} & \multicolumn{2}{|c|}{ Day 23} & \multicolumn{2}{|r|}{ Day 30} \\
\hline & Control & xperimen & Contro & 1 Experimental & Control & Experimental & Control & Experimental & Control & 1 Experimental \\
\hline $20 \%$ & 58.6 & 59.4 & 59.0 & 60.1 & 58.3 & 60.1 & 58.1 & 61.2 & 56.4 & 61.6 \\
\hline $15 \%$ & 58.6 & 58.9 & 59.0 & 59.6 & 59.8 & 60.0 & 59.8 & 60.5 & 58.2 & 61.3 \\
\hline $10 \%$ & 56.9 & 57.8 & 57.6 & 58.0 & 58.9 & 59.5 & 57.0 & 60.7 & 58.1 & 60.2 \\
\hline $5 \%$ & 56.9 & 58.1 & 58.0 & 58.9 & 58.0 & 59.2 & 57.8 & 59.7 & 58.8 & 60.2 \\
\hline $1 \%$ & 55.7 & 56.0 & 55.0 & 56.0 & 56.4 & 57.2 & 55.1 & 57.8 & 58.9 & 59.1 \\
\hline
\end{tabular}




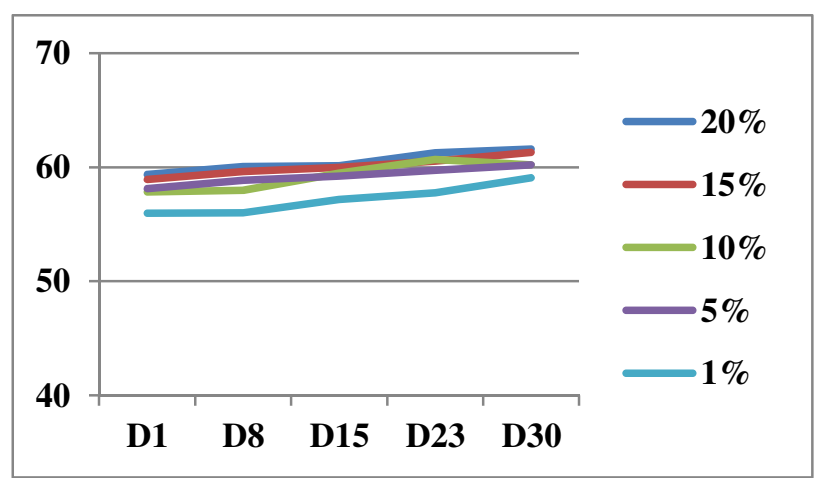

Figure10. Whitening effect of rice bran fermentation solution

Whitening improvement rate $=\frac{\text { experimental group }(\text { day } 28)-\text { control group }(\text { day } 28)}{\text { control group }(\text { day } 28)} \times 100 \%$

Table 5. Whitening improvement rate of rice bran fermentation solution after 30 days
Variable
Value

\begin{tabular}{lccccc}
\hline Diluted solution & $20 \%$ & $15 \%$ & $10 \%$ & $5 \%$ & $1 \%$ \\
Whitening improvement rate & $9.29 \%$ & $5.36 \%$ & $3.69 \%$ & $2.43 \%$ & $0.35 \%$ \\
\hline
\end{tabular}

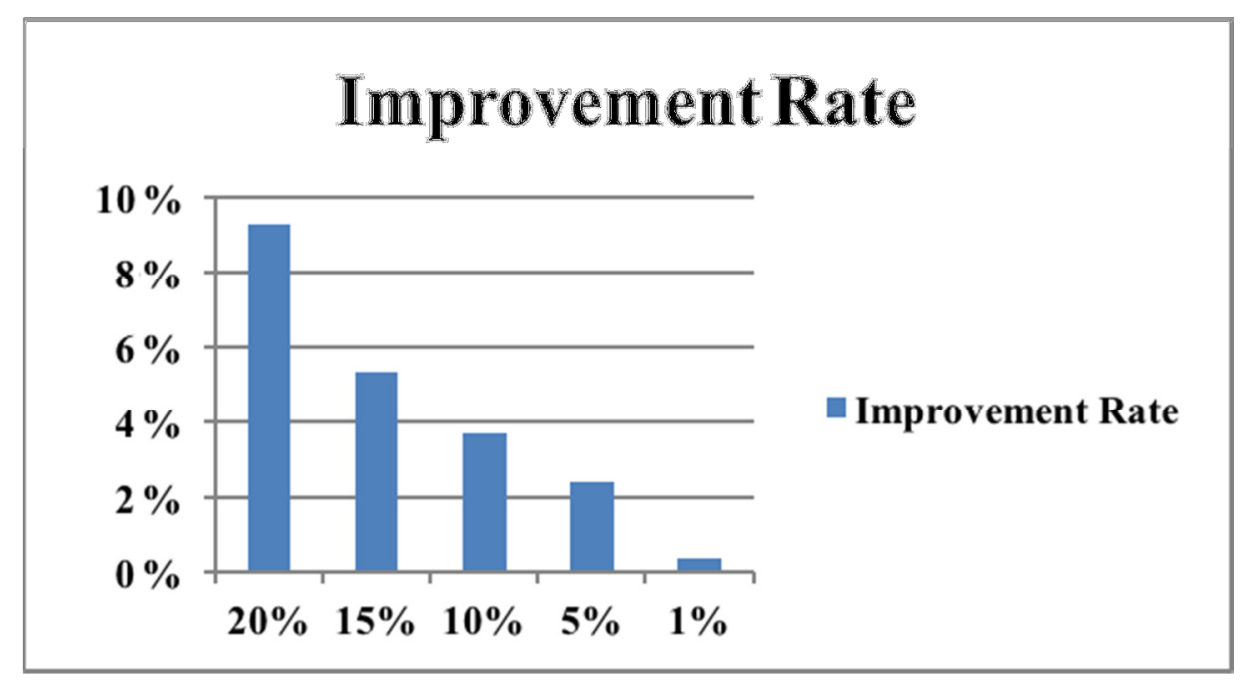

Figure 11. Whitening improvement rate of rice bran fermentation solution after 30 days

After 30 days of test on 20 females aged 18 to 20 , the results showed that the higher the concentration of the diluted rice bran fermentation solution is, the better the whitening effect is. Based on the experimental data, the $20 \%$ rice bran fermentation solution had the best moisturizing effect.

According to the results of other studies, the whitening improvement rate of $7.8 \%$ sake lees was $3.24 \%$; and that of $8.43 \%$ beer lees and $3.16 \%$ rice wine lees was $2.26 \%$ and $1.33 \%$, respectively. Based on our experimental results above, when the concentration of the rice bran fermentation solution was between $5 \%$ and $10 \%$, the whitening improvement rate was between $2.43 \%$ and $3.69 \%$, which was comparable to other lees. Moreover, the rice bran fermentation solution is alcohol-free, and thus it does not irritate skin. In addition to whitening, the effects of moisturizing, antioxidation, melanin synthesis inhibition were proved by experiments and usage. As a result, the rice bran fermentation solution can be added to cosmetics formula as a natural raw material of skin care products. The use of rice bran to obtain the fermentation solution is also an environmentally correct alternative, since it reduces its disposal in nature. 
RESUMO: Este estudo tem como objetivo desenvolver produtos de cuidados com a pele baseados em farelo de arroz com hidratação, branqueamento e efeitos antiarrugas semelhantes à Pitera (um subproduto natural da fermentação de sauces), mas sem irritação com álcool para a pele sensível. Para alcançar esse objetivo, o farelo do arroz indica orgânico foi fermentado por bactérias do ácido lático em um ambiente seguro e livre de poluição.

Em termos de antioxidação, a capacidade de eliminação radical de DPPH.free de 100,0 mg / mL de solução de fermentação de farelo foi de $71,4 \%$ da vitamina $C$ da mesma concentração; E sua capacidade de quelação Fe $2+$ foi de $79,0 \%$ da EDTA da mesma concentração. Além disso, a capacidade de eliminação de aniões superóxido de 10,0 mg / mL de solução de fermentação de farelo era equivalente a 42,9\% da BHT de concentração similar. Com relação à inibição da síntese de melanina, a capacidade da solução de fermentação do farelo de inibir a síntese do dopachrome, o intermediário da melanina, correlacionou-se positivamente com sua concentração, ou seja, quanto maior a concentração da solução de fermentação do farelo, melhor a capacidade de inibição estava. A solução de IC50 de fermentação de farelo foi de 9,23 mg / mL enquanto que, para comparação, a arbutina era de 0,52 mg / mL. Além disso, de acordo com o ensaio de sobrevivência celular, nenhum efeito citotóxico óbvio foi encontrado com o aumento da concentração da solução de fermentação de farelo. Quanto à avaliação do branqueamento, a taxa de branqueamento foi de 9,29\% na diluição de $20 \%$, $5,36 \%$ na diluição de $15 \%, 3,69 \%$ na diluição de $10 \%, 2,43 \%$ na diluição de $5 \%, 0,35 \%$ na diluição de $1 \%$ em um teste de 30 dias . Na avaliação hidratante, a taxa de melhora hidratante foi de 44,31\% em $20 \%$ de diluição, $20,48 \%$ em diluição de $15 \%, 7,68 \%$ em diluição de $10 \%, 6,02 \%$ em diluição de $5 \%$ e 2,02\% em diluição a $1 \%$.

Com base nos resultados experimentais, a solução de fermentação de farelo de arroz sem álcool não só não causou irritação, mas também teve anti-envelhecimento, inibição da síntese de melanina, branqueamento e efeitos hidratantes. Portanto, é aconselhável adicionar solução de fermentação de farelo de arroz para mousse de limpeza, gel de banho, soro e essência para transformar o farelo do composto de resíduos agrícolas (berço a túmulo) em uma matéria-prima natural (berço para berço) da indústria de cosméticos, criando Novo valor do farelo de arroz.

PALAVRAS-CHAVE: Brilho de arroz. Bactérias de ácido lático. Fermentação sem álcool. Antioxidação. Anti-envelhecimento. Branqueamento. Cosméticos.

\section{REFERENCES}

FUH, W. S. Utilization of rice bran for manufacturing nutritional and functional food ingredients. Master's Degree in Food Technology, National Taiwan University, Taiwan, 2001.

CHAO, K. S.; CHANG, H. M. Cosmetics Chemistry. Taipei: Wu-Nan Book Inc., 2006.

PENG, H. T. Use of Bacillus subtilis var. natto, Saccharomyces cerevisae, and Aspergillus oryzae in fermentation of brown rice. Master's Degree in Molecular Biotechnology, Dayeh University, Taiwan, 2007.

$\mathrm{Wu}, \mathrm{K}$. H. Study on preparation of a fermented drink made from brown rice and its antioxidative properties. Master's Degree in Food Science and Biotechnology, National Chung Hsing University, Taiwan, 2007.

TU, M. C. Studies on whitening and antioxidation effect analysis from lees fermented by lactic acid bacteria. Master's Degree in Bioengineering, Tatung University, Taiwan, 2010.

YEUNG, C. K. Studies on preparation of lactic acid bacteria-fermented rice bran drink by two step fermentation and on upgrading utilization of rice bran. Master's Degree in Food Science and Biotechnology, National Chung Hsing University, Taiwan, 2011.

CHANG, Y. C.; CHOU, Y. C,; TSENG, C. H. The magic beauty effect of rice bran. Taichung: Taichung Municipal Taichung Home Economics and Commercial High School, 2012, p12-46.

LIOU, H. C. Study on the skin whitening- and anti-oxidant effects of alcohol extraction- and fermentation of natural products. Master's Degree in Cosmetics Technology, Hungkuang University, Taiwan, 2012.

WU, C. Y. Study on the possible whitening mechanism of [6]-shogaol. Master's Degree in Cosmetics Technology, Hungkuang University, Taiwan, 2013. 
TSAI, C. H. The antioxidative, anti-inflammatory and tyrosinase inhibition activities of Taiwan japonica 9 germinated brown rice extracts. Master's Degree in Bio-industry Technology, Dayeh University, Taiwan, 2014.

CHANG, L. Research on the functionality of rice fermented with Bacillus natto. Master's Degree in Applied Science of Living, Chinese Culture University, Taiwan, 2014.

CHEN, Y. W. Effect of combination of hydrolysis and LAB fermentation on the functionality of brown rice. Master's Degree in Food Science, National Taiwan Ocean University, Taiwan, 2014.

LIN, Y. C. Tyrosinase inhibiting ingredients and their applications in cosmetics. Master's Degree in Bioindustry Technology, Dayeh University, Taiwan, 2014.

LU, C. H. The investigation of the effects in different lipids and polysaccharides addition on the physical properties and moisturizing capabilities of soap. Master's Degree in Biotechnology, Dayeh University, Taiwan, 2014.

HSUEH, C. Y. The anti-oxidation and moisturizing effect of Tremella fuciformis extract and its application in cosmetics. Master's Degree in Applied Cosmetology and Cosmetic Science, Hung Kuang University, Taiwan, 2014.

HE, J. Y. Anti-inflammatory Activities of Rice Bran Functional Components. Master's Degree in Biotechnology, Asia University, Taiwan, 2014.

LERNER, A. B.; FITZPARTICK, T. B. Biochemistry of melanin formation. Physiological Reviews, v. 30, n. 1, p. 91-126, 1950. https://doi.org/10.1152/physrev.1950.30.1.91

FRIED, R. Colorimetric determination of xanthine dehydrogenase by tetrazolium reduction. Anal. Biochem., v. 16, p. 427- 432, 1966. https://doi.org/10.1016/0003-2697(66)90224-7

MANNING, J. M.; MEISTER, A. Conversion of Proline to Collagen Hydroxyproline. Biochemistry, v. 5, n. 4, p. 1154- 1165, 1966. https://doi.org/10.1021/bi00868a007

MAYER, A. M. Polyphenol oxidases in plants-recent progress. Phytochemistry, v. 26, n. 1, p. 11-20, 1986. https://doi.org/10.1016/S0031-9422(00)81472-7

VILLAREAL, C. P.; MARANVILLE, J. W.; JULIANO, B. O. Nutrient content and retention during milling of brown rices from the international rice research institute. Cereal Chemistry. v. 68, n. 4, p. 437-439, 1991.

DINIS, T. C. P.; MADEIRA, V. M. C.; ALMEIDA, L. M. Action of phenolic derivatives (acetanibophen, salicylate, and 5-aminosalicylate) as inhibitors of membrane lipid peroxidation and as peroxyl radical scavengers. Arch. Biochem. Biophys., v. 315, p. 161-169, 1994. https://doi.org/10.1006/abbi.1994.1485

LEE, K. T.; KIM, B. J.; KIM, J. H. Biological screening of 100 plant extracts for cosmetic use (I): inhibitory activities of tyrosinase and dopa- autooxidation. Int. J. Cosmet. Sci., v. 19, p. 291-298, 1997.

https://doi.org/10.1046/j.1467-2494.1997.171725.x

https://doi.org/10.1111/j.1467-2494.1997.tb00193.x

CHNAG, L. Application of cosmetics Inspecting. Fayfar Publishing Co., Ltd, Taiwan. 1998 p. 126-168.

YAMAGUCHI, T.; TAKAMURA, H.; MATOBA T. T.; TERAO, J. HPLC method for evaluation of the free radical- scavenging activity of foods by using 1,1-diphenyl-2-picrylhydrazyl. Biosci. Biotechnol. Biochem., v. 62, p. 1201-1204, 1998. https://doi.org/10.1271/bbb.62.1201 
KAZUHO, A.; HIROSHI, S. Both oxidative stress- dependent and independent effects of amyloid $\beta$ protein are detected by 3-(4, 5-dimethylthiazol- 2-yl)-2, 5-diphenyltetrazolium bromide (MTT) reduction assay. Brain Research, v. 830, p. 146-154, 1999. https://doi.org/10.1016/S0006-8993(99)01421-3

KAYAHARA, H.; TSUKAHARA, K.; TATAI, T. Flavor health and nutritional quality of pregerminated brown rice. Department of Bioscience and Biotechnology, Shimshu University, Minamiminowa, Kamiina, Nagano, Japan. p. 399-459, 2000

ZHOU, J. Introduction of the whitening cosmetics. A news letter of food and drug, v. 256, p. 3-5, 2002.

GREATENS, A.; HAKOZAKI, T.; KOSHOFFER, A.; EPSTEIN, H.; SCHWEMBERGER, S.; BABCOCK, G.; BOISSY, R.E. Effective inhibition of melanosome transfer to keratinocytes by lectins and niacinamide is reversible. Experimental Dermatology, v. 14, n. 7, p. 498-508, 2005. https://doi.org/10.1111/j.09066705.2005.00309.x 